\title{
RELATIONSHIPS IN THE WORKPLACE AND OCCUPATIONAL ATTRACTIVENESS AMONG STUDENTS, TEACHERS AND RANGERS-SPORTSMEN
}

\author{
Nikolay Ivantchev, Stanislava Stoyanova \\ South-West University "Neofit Rilski", Bulgaria \\ E-mail: avka@abv.bg
}

\begin{abstract}
Perceived occupational attractiveness could be due to many factors and relationships in the workplace are among them. The questionnaire "Attractiveness of the profession" created by Ivanov (1999) was used to study how relationships in the workplace were related to perceptions of occupational attractiveness among students, teachers and rangers-sportsmen participating in special missions abroad. In 2012 and 2013, 46 secondary school teachers, 40 students in pedagogical specialties, and 27 sportsmen-rangers participating in special missions abroad were studied in Bulgaria. The results indicated that the students and the rangers were more satisfied with their work than the teachers were. The interpersonal relationships influenced mainly the students' and rangers'perceptions of occupational attractiveness. The rangers were more influenced by the relationships with the colleagues. The psycho-climate in the workplace was considered as more important by the rangers. The students were more influenced by the interpersonal communication at the workplace and their heads' expertise. Some moderators of interpersonal relationships in the workplace were found - such as the tasks in the work, the prestige of occupation, the interaction between occupation and rewards, and the psycho-climate in the workplace.
\end{abstract}

Key words: relationships in the workplace, occupational attractiveness, students, teachers, rangerssportsmen.

\section{Introduction}

Occupations serve as a social mechanism through which rewards are allocated, power exercised and esteem allotted in modern society. Occupations have different prestige and socioeconomic status (Samuel \& Yuchtman-Yaar, 1979). A profession could become a means for demonstrating superiority (Adler, 1997a). Occupational attractiveness is a combination of perceived qualities, status, performance, and respect related to the profession.

The attractiveness of the profession is not related only to the possibilities of exercising prestige and power. There are a lot of other factors that could contribute to perceiving an occupation as attractive. The dimensions of job attractiveness are competency, self-direction, interpersonal relations, extrinsic outcomes and intrinsic outcomes (Fields \& Shallenberger, 1987).

According to Moses (2003, pp. 27-55), career motivational type of Sociability seekers love working closely in group environments, where there are a lot of social interactions. A Sociability seeker wants to get to know the colleagues, team-mates or clients personally. A Sociability seeker 
feels a strong sense of loyalty to their co-workers. Whatever is the structure of the work, the joy of it flows from the relationships developed and established with co-workers and clients.

The motivation for work of Sociability seekers increases with the age and with the length of service (time of work experience) and it is more typical for female workers (Slavchov \& Stoyanova, 2007). Some other authors also indicate several sociodemographic differences in work attractiveness.

Occupations characterized by involvement with data, extensive training, and workers' ability to control the nature and pace of their work are attractive to older workers (Hayward, 1986). Major, grade level, and gender are associated with occupational attractiveness among the students (Courtright \& Mackey, 2004). The males with high occupational status are viewed as highly attractive and competent in their work. Females assess other females as more attractive and more competent than do their male counterparts (Hickling, Noel \& Yutzler, 1979).

The importance of some social - demographic factors for perceived occupational attractiveness has been revealed by some other studies (Courtright \& Mackey, 2004; Hayward, 1986; Hickling, Noel \& Yutzler, 1979; Slavchov \& Stoyanova, 2007). This study is focused on the characteristics of the job related to occupational attractiveness, especially on the relationships in the workplace, whose effect could be moderated by the psycho-climate at the workplace, tasks, rewards, prestige, leisure time, and intellectual and creative dimensions of work. The relationships are very important for occupational attractiveness, because it has been found that teachers with a wider and helpful network of support express greater levels of satisfaction and commitment to their jobs (Berry, 2012).

The aim of this study was to investigate how relationships in the workplace were related to occupational attractiveness for students, teachers and rangers-sportsmen participating in special missions abroad. The hypothesis of the study was that the relationships in the workplace would be more related to occupational attractiveness for the rangers-sportsmen participating in special missions abroad than for the students in pedagogical specialties and the teachers.

\section{Methodology of Research}

\section{General Characteristics of Research}

The three groups of participants (the rangers-sportsmen participating in special missions abroad, the students in pedagogical specialties, and the teachers) were compared, because the students practiced teaching in the secondary schools in Bulgaria, and they also practiced sport as a part of their academic curriculum of study.

\section{Participants}

All participants took part in the study voluntarily. They were recruited purposefully to be the representatives of the occupational groups of teachers, students in pedagogical specialties who practiced the teaching occupation in the secondary schools, and rangers-sportsmen. A total number of 113 subjects agreed to participate in the study of approximatively 150 subjects who were approached initially. The period of data collection lasted for several months.

In November 2012, 46 secondary school teachers participated in the study in Blagoevgrad. 7 were men, the others were women. The teachers were from newly-hired teachers to those having just several months to retirement. They taught different subjects - foreign languages like French, Spanish, English, German $(\mathrm{N}=18)$; mathematics $(\mathrm{N}=4)$; information technologies $(\mathrm{N}=4)$; biology $(\mathrm{N}=3)$; chemistry $(\mathrm{N}=3)$; physics $(\mathrm{n}=3)$; physical education and sport $(\mathrm{N}=3)$; Bulgarian language and literature $(\mathrm{N}=3)$; history and civilization $(\mathrm{N}=2)$; fine arts $(\mathrm{N}=2)$; philosophy $(\mathrm{N}=1)$.

In April and May 2013, 40 students in pedagogical specialties were studied at South-West University "Neofit Rilski” in Blagoevgrad, Bulgaria. 33 were women and 7 were men. Their age was from 21 to 30 years old. Their specialties were Bulgarian philology $(\mathrm{N}=20)$; Balkan studies $(\mathrm{N}=7)$; Slav philology $(\mathrm{N}=6)$; other foreign languages $(\mathrm{N}=4)$; mathematics $(\mathrm{N}=2)$; physical education $(\mathrm{N}=1)$. They were from different parts of Bulgaria.

In July 2013, 27 sportsmen-rangers participating in special missions abroad participated in the study in Sofia. They were 26 men and 1 woman. 
The majority of males (mainly rangers) and females (mainly teachers) in our sample were from different kinds of occupation that is why, no gender differences would be investigated. Otherwise, they would reflect only inter-occupational, not intra-occupational differences.

\section{Instrument and Data Analysis}

The questionnaire "Attractiveness of the profession" was used (Ivanov, 1999, pp. 15-17). It was designed for the teaching profession. It enumerates 33 aspects of the occupation concerning creativity and intellect, ethics at the workplace, social-economic status of the occupation, organization and management, hygienic conditions, and leisure time.

The answers varied from 1 (not at all true) to 5 (true). They were recoded into 1 (a positive answer preferring this occupational aspect - former 4 and 5) and 0 (a negative answer not liking this occupational aspect - former 1,2 and 3). The author does not indicate any reliability coefficient. In this sample, Cronbach' alpha was $r=.958$ for the total scale and no negative correlations between the items were found.

The data was processed by means of the statistical software SPSS 16.0. Descriptive statistics and chi-square analysis were used. Univariate General linear model was applied. The dependent variable was "Occupational attractiveness because of interpersonal relationships". The random factors were gender and occupation. The covariates in the model were "Occupational attractiveness because of psycho-climate", "Occupational attractiveness because of leisure time", "Occupational attractiveness because of tasks", "Occupational attractiveness because of rewards", "Occupational attractiveness because of prestige", "Occupational attractiveness because of rewards", "Occupational attractiveness because of head's expertise" and "Occupational attractiveness because of intellectual and creative dimensions of work".

\section{Results of Research}

Occupational attractiveness has several dimensions presented in Table 1 with their indicators that were measured.

Table 1. Number of participants (students in pedagogical specialities, teachers and sportsmen-rangers) who preferred each of the dimensions of occupational attractiveness.

\begin{tabular}{|c|c|c|c|c|}
\hline \multicolumn{2}{|c|}{ Dimensions of occupational attractiveness } & \multirow{2}{*}{$\begin{array}{c}\begin{array}{c}\text { Students in } \\
\text { pedagogical } \\
\text { specialities } \\
(\mathrm{N}=40)\end{array} \\
36\end{array}$} & \multirow{2}{*}{$\begin{array}{c}\begin{array}{c}\text { Teachers } \\
(\mathrm{N}=46)\end{array} \\
13\end{array}$} & \multirow{2}{*}{$\begin{array}{c}\begin{array}{c}\text { Sportsmen- } \\
\text { rangers } \\
(\mathrm{N}=27)\end{array} \\
16\end{array}$} \\
\hline Intellectual and creative & $\begin{array}{l}\text { Creative character of the } \\
\text { occupation }\end{array}$ & & & \\
\hline & High level of intellectual work & 35 & 10 & 17 \\
\hline \multicolumn{2}{|c|}{ Authentic expression of oneself } & 30 & 9 & 21 \\
\hline \multirow{3}{*}{ Prestige of the work } & $\begin{array}{l}\text { Perceived nobility of the } \\
\text { occupation }\end{array}$ & 35 & 13 & 20 \\
\hline & $\begin{array}{l}\text { High social prestige of } \\
\text { occupation }\end{array}$ & 23 & 2 & 15 \\
\hline & $\begin{array}{l}\text { Participation in youth } \\
\text { preparation for life }\end{array}$ & 38 & 10 & 20 \\
\hline
\end{tabular}




\begin{tabular}{|c|c|c|c|c|}
\hline \multicolumn{2}{|c|}{ Dimensions of occupational attractiveness } & \multirow{2}{*}{$\begin{array}{c}\begin{array}{c}\text { Students in } \\
\text { pedagogical } \\
\text { specialities } \\
(\mathrm{N}=40)\end{array} \\
19\end{array}$} & \multirow{2}{*}{$\begin{array}{c}\begin{array}{c}\text { Teachers } \\
\text { ( }=46)\end{array} \\
1\end{array}$} & \multirow{2}{*}{$\begin{array}{c}\begin{array}{c}\text { Sportsmen- } \\
\text { rangers } \\
(\mathrm{N}=27)\end{array} \\
14\end{array}$} \\
\hline \multirow{6}{*}{$\begin{array}{l}\text { Interpersonal } \\
\text { relationships }\end{array}$} & $\begin{array}{l}\text { Colleagues' dedicated attitude } \\
\text { towards their job }\end{array}$ & & & \\
\hline & Colleagues' lack of envy & 13 & 3 & 11 \\
\hline & Colleagues' modesty & 9 & 3 & 13 \\
\hline & Colleagues' gender & 4 & 2 & 10 \\
\hline & $\begin{array}{l}\text { The possibility for permanent } \\
\text { occupation with social work }\end{array}$ & 26 & 2 & 19 \\
\hline & $\begin{array}{l}\text { The possibility for constant } \\
\text { contacts with youth }\end{array}$ & 38 & 20 & 15 \\
\hline The heads' expertise & High heads' competence & 23 & 5 & 14 \\
\hline \multirow{3}{*}{$\begin{array}{l}\text { Psycho-climate at } \\
\text { workplace }\end{array}$} & quiet and calm workplace & 13 & 1 & 13 \\
\hline & Cleanliness of the workplace & 16 & 0 & 16 \\
\hline & $\begin{array}{l}\text { Peaceful environment with } \\
\text { lack of tension }\end{array}$ & 9 & 1 & 13 \\
\hline \multirow{3}{*}{ Rewards } & Just payment & 9 & 3 & 12 \\
\hline & High salary & 7 & 3 & 8 \\
\hline & $\begin{array}{l}\text { A lot of possibilities for } \\
\text { additional work stimulation }\end{array}$ & 13 & 3 & 7 \\
\hline \multirow{3}{*}{ Tasks } & Stability of the requirements & 20 & 3 & 13 \\
\hline & Diversity & 29 & 2 & 19 \\
\hline & $\begin{array}{l}\text { The requirement to execute a } \\
\text { few inappropriate duties }\end{array}$ & 6 & 1 & 10 \\
\hline \multirow{2}{*}{ Ample leisure time } & Long-term leave & 28 & 10 & 16 \\
\hline & Ample free time & 26 & 4 & 14 \\
\hline
\end{tabular}

The intellectual and creative dimensions of the work were the most preferred by the students:

The creative character of the occupation was the most liked by the students in pedagogical specialities ( $90 \%$ of the students), followed by the sportsmen-rangers (59.3\% of the rangers) and lastly by the teachers ( $28.3 \%$ of the teachers) $\left(\chi_{|2|}{ }^{2}=33.42 ; \mathrm{p}<.001\right)$.

The high level of intellectual work was the most liked by the students in pedagogical specialities ( $87.5 \%$ of the students), followed by the sportsmen-rangers ( $63 \%$ of the rangers) and lastly by the teachers (21.7\% of the teachers) $\left(\chi_{|2|}{ }^{2}=38.303 ; \mathrm{p}<.001\right)$.

The authentic expression of oneself was considered as more attractive by the rangers:

The possibility of authentic expression of oneself was the most liked by the sportsmen-rangers (77.8\% of the rangers), followed by the students in pedagogical specialities (75\% of the students), and the least liked by the teachers ( $19.6 \%$ of the teachers) $\left(\chi_{|2|}{ }^{2}=35.078 ; \mathrm{p}<.001\right)$.

The prestige of the work was the most liked by the students:

The perceived nobility of the occupation was liked the most by the students in pedagogical specialities ( $87.5 \%$ of the students), followed by the sportsmen-rangers ( $74.1 \%$ of the rangers) and was the least liked by the teachers ( $28.3 \%$ of the teachers) $\left(\chi_{|2|}{ }^{2}=34.19 ; \mathrm{p}<.001\right)$.

High social prestige of occupation was the most liked by the students in pedagogical specialities (57.5\% of the students), followed by the sportsmen-rangers (55.6\% of the rangers) and was the least liked by the teachers ( $4.3 \%$ of the teachers) $\left(\chi_{|2|}{ }^{2}=32.736 ; \mathrm{p}<.001\right)$.

Participation in youth preparation for life was the most liked by the students in pedagogical specialities ( $95 \%$ of the students), followed by the sportsmen-rangers $(74.1 \%$ of the rangers) and the least liked by the teachers $(21.7 \%$ of the teachers $)\left(\chi_{|2|}{ }^{2}=50.777 ; \mathrm{p}<.001\right)$. 
The interpersonal relationships influenced mainly the rangers' and students' perceptions of occupational attractiveness. The rangers were more influenced by the relationships with the colleagues:

Colleagues' dedicated attitude towards their job was the most appreciated by the sportsmenrangers (51.9\% of the rangers), followed by the students in pedagogical specialities ( $47.5 \%$ of the students), and was the least liked by the teachers ( $2.2 \%$ of the teachers) $\left(\chi_{|2|}{ }^{2}=28.884 ; \mathrm{p}<.001\right)$.

Colleagues' lack of envy was indicated as important most frequently by the sportsmen-rangers ( $40.7 \%$ of the rangers), followed by the students in pedagogical specialities (32.5\% of the students), and the least frequently by the teachers ( $6.5 \%$ of the teachers) $\left(\chi_{|2|}{ }^{2}=13.477 \mathrm{p}<.001\right)$.

Colleagues' modesty was marked as important most frequently by the sportsmen-rangers ( $48.1 \%$ of the rangers), followed by the students in pedagogical specialities ( $22.5 \%$ of the students), and the least frequently by the teachers $(6.5 \%$ of the teachers $)\left(\chi_{|2|}{ }^{2}=17.116 ; \mathrm{p}<.001\right)$.

Colleagues' gender was noted as a factor to the occupational attractiveness most frequently by the sportsmen-rangers ( $37 \%$ of the rangers), followed by the students in pedagogical specialities ( $10 \%$ of the students), and lastly by the teachers ( $4.3 \%$ of the teachers) $\left(\chi_{|2|}{ }^{2}=15.839 ; \mathrm{p}<.001\right)$.

The possibility for permanent occupation with social work was the most liked by the sportsmen-rangers ( $70.4 \%$ of the rangers), followed by the students in pedagogical specialities (65\% of the students), and the least liked by the teachers ( $4.3 \%$ of the teachers) $\left(\chi_{|2|}{ }^{2}=44.492 ; \mathrm{p}<.001\right)$.

The possibility for constant contacts with youth was the most liked by the students in pedagogical specialities ( $95 \%$ of the students), followed by the sportsmen-rangers ( $55.6 \%$ of the rangers) and the least liked by the teachers ( $43.5 \%$ of the teachers) $\left(\chi_{|2|}{ }^{2}=26.105 ; \mathrm{p}<.001\right)$.

The heads' expertise was considered as more attractive by the students:

High heads' competence was the most liked by the students in pedagogical specialities $(57.5 \%$ of the students), followed by the sportsmen-rangers (51.9\% of the rangers) and the least liked by the teachers ( $10.9 \%$ of the teachers) $\left(\chi_{|2|}{ }^{2}=23.196 ; \mathrm{p}<.001\right)$.

Psycho-climate at workplace was considered as more important by the rangers.

The quiet and calm workplace was indicated as important more frequently by the sportsmenrangers ( $48.1 \%$ of the rangers), followed by the students in pedagogical specialities $(32.5 \%$ of the students), and the least frequently by the teachers ( $2.2 \%$ of the teachers) $\left(X_{|2|}{ }^{2}=22.297 ; \mathrm{p}<.001\right)$.

Cleanliness of the workplace had the most importance amongst the sportsmen-rangers $(59.3 \%$ of the rangers), followed by the students in pedagogical specialities ( $40 \%$ of the students), and lastly the teachers (no one) $\left(\chi_{|2|}{ }^{2}=33.595 ; \mathrm{p}<.001\right)$.

Peaceful environment with lack of tension was indicated the most frequently by the sportsmen-rangers ( $48.1 \%$ of the rangers), followed by the students in pedagogical specialities $(20 \%$ of the students), and the least frequently by the teachers ( $2.2 \%$ of the teachers $)\left(\chi_{|2|}{ }^{2}=22.947 ; \mathrm{p}<.001\right)$.

The rewards were considered as more attractive by the rangers and the students. The teachers were disappointed in their work payment.

The just payment was indicated the most frequently by the sportsmen-rangers ( $44.4 \%$ of the rangers), followed by the students in pedagogical specialities (22.5\% of the students), and the least frequently by the teachers ( $6.5 \%$ of the teachers) $\left(\chi_{|2|}{ }^{2}=14.686 ; \mathrm{p}=.001\right)$.

The high salary was indicated the most frequently by the sportsmen-rangers $(29.6 \%$ of the rangers), followed by the students in pedagogical specialities (17.5\% of the students), and the least frequently by the teachers ( $6.5 \%$ of the teachers) $\left(\chi_{|2|}{ }^{2}=6.898 ; \mathrm{p}=.032\right)$.

A lot of possibilities for additional work stimulation were indicated the most frequently by the students in pedagogical specialities ( $32.5 \%$ of the students), followed by the sportsmen-rangers (25.9\% of the rangers) and the least frequently by the teachers ( $6.5 \%$ of the teachers) $\left(\chi_{|2|}{ }^{2}=9.586\right.$; $\mathrm{p}=.008)$.

The tasks were considered as more attractive by the students and the rangers:

The stability of the requirements was indicated the most frequently by the students in pedagogical specialities ( $50 \%$ of the students), followed by the sportsmen-rangers ( $48.1 \%$ of the rangers) and the least frequently by the teachers (6.5\% of the teachers) $\left(\chi_{|2|}{ }^{2}=22.967 ; \mathrm{p}<.001\right)$.

Diversity was the most liked by the students in pedagogical specialities ( $72.5 \%$ of the students), followed by the sportsmen-rangers ( $70.4 \%$ of the rangers) and the least liked by the teachers $(4.3 \%$ of the teachers) $\left(\chi_{|2|}^{2}=50.097 ; \mathrm{p}<.001\right)$. 
The requirement to execute a few inappropriate duties was indicated the most frequently by the sportsmen-rangers ( $37 \%$ of the rangers), followed by the students in pedagogical specialities $(15 \%$ of the students), and the least frequently by the teachers ( $2.2 \%$ of the teachers) $\left(\chi_{|2|}{ }^{2}=16.18 ; \mathrm{p}<.001\right)$.

Ample leisure time was considered as more attractive by the students:

The long-term leave was the most liked by the students in pedagogical specialities $(70 \%$ of the students), followed by the sportsmen-rangers (59.3\% of the rangers) and the least liked by the teachers $\left(21.7 \%\right.$ of the teachers) $\left(\chi_{|2|}{ }^{2}=21.843 ; \mathrm{p}<.001\right)$. Similarly, the ample free time was appreciated the most by the students in pedagogical specialities (65\% of the students), followed by the sportsmen-rangers ( $51.9 \%$ of the rangers) and the least by the teachers ( $8.7 \%$ of the teachers) $\left(\chi_{|2|}{ }^{2}=31.015 ; \mathrm{p}<.001\right)$.

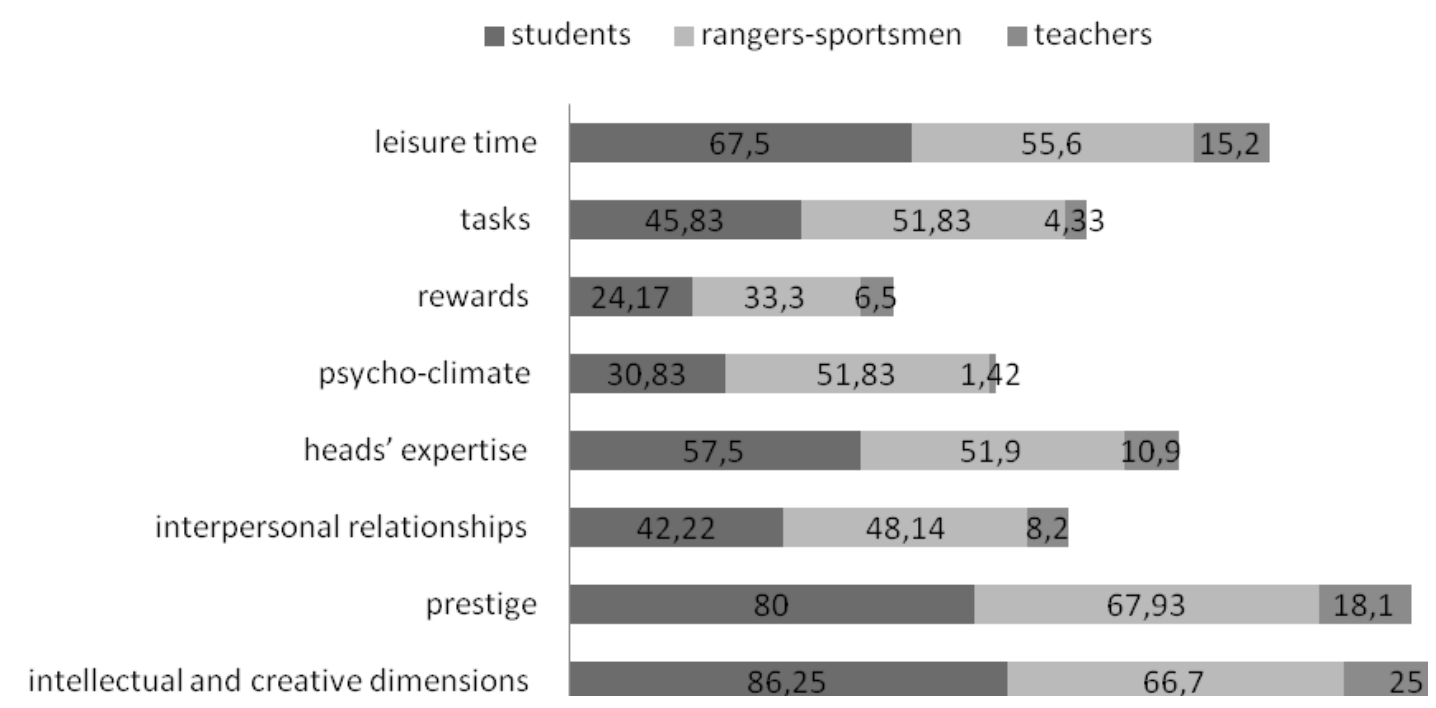

Figure 1: Mean percentages of the dimensions of occupational attractiveness for the students, the teachers and the rangers.

The most attractive occupational aspects for the three kinds of occupations were the intellectual and creative dimensions, and the prestige of the work, followed by the leisure time and head's eexpertise, then - the tasks and the interpersonal relations, then - psycho-climate. The rewards were the least satisfying for all three kinds of occupations (see Figure 1).

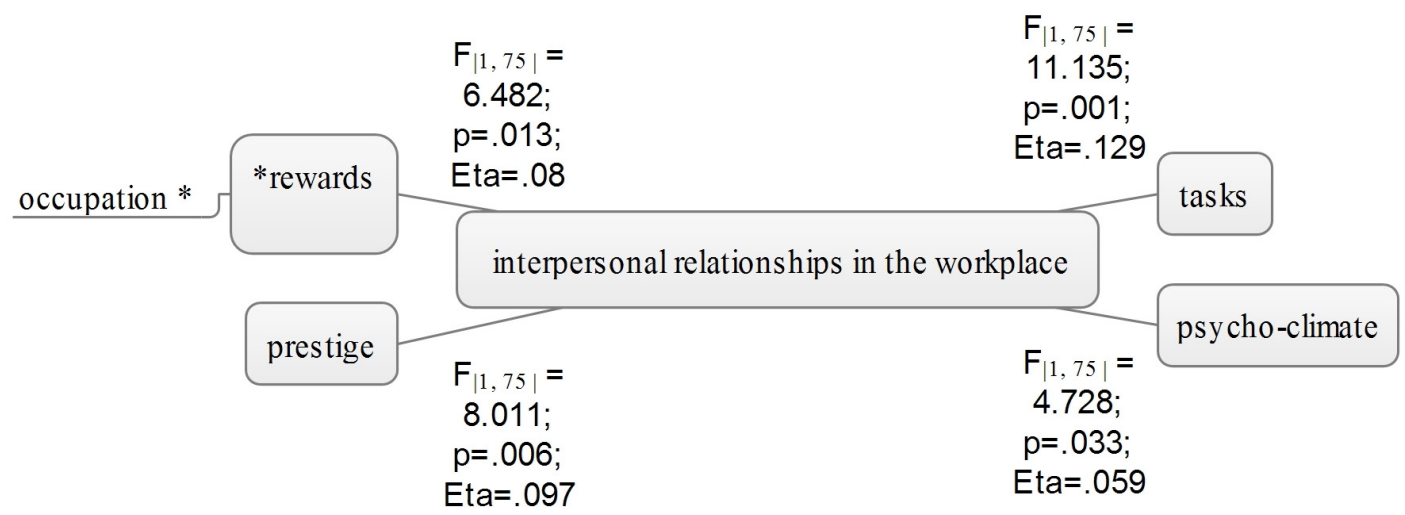

Figure 2: $\quad$ Results from Univariate general linear model regarding significant moderators influencing Occupational attractiveness because of interpersonal relationships in the workplace. 
Interpersonal relationships in the workplace were the most strongly moderated by the tasks, followed by the prestige of occupation, then by the interaction between occupation and rewards, and the most weakly moderated by the psycho-climate in the workplace (see Figure 2).

\section{Discussion}

The aspects of work tasks such as the stability of the requirements, diversity, and the required execution of a few inappropriate duties increased occupational attractiveness related to interpersonal relationships in the workplace.

The perceived prestige of occupation expressed as nobility of the occupation, high social prestige of occupation, and participation in youth preparation for life increased also occupational attractiveness related to interpersonal relationships in the workplace.

The rewards in the form of perceived just payment, high salary, and a lot of possibilities for additional work stimulation interacted with occupation (teachers, students in pedagogical majors and rangers-sportsmen) to increase occupational attractiveness related to interpersonal relationships in the workplace. Both occupational attractiveness related to rewards and interpersonal relationships in the workplace were higher among students in pedagogical majors and rangers-sportsmen than among teachers.

The psycho-climate in the form of quiet and calm workplace, cleanliness of the workplace, and peaceful environment with lack of tension increased occupational attractiveness related to interpersonal relationships in the workplace.

The hypothesis of the study was proved. Some differences were found in occupational attractiveness between students, teachers and rangers-sportsmen. The students and the rangers were more satisfied with their work than the teachers. The students preferred the intellectual and creative dimensions of the job, the perceived prestige of the occupation, the ample leisure time, and the heads' expertise. The rangers considered as more attractive occupational aspects the authentic expression of oneself, the psycho-climate at the workplace, the relationships with the colleagues, the tasks, and the rewards. The similar tendencies were found in other studies.

Flexible work schedule was a very important reason for choosing a job by students (Larkin, Laport \& Pines, 2007). For both military and ex-army personnel, high leader support, low job conflict, and high challenge are related to high levels of job satisfaction (Alpass et al., 1997). Perceived leader support is more important for rangers' performance motivation than peer support (Weiner, 1990). The importance of rewards is especially significant for teaching occupation. The psychic rewards of teaching (such as approval, recognition, etc.) provide the main basis of commitment and professional work satisfaction (Troman, 2008).

Low level of teachers' work satisfaction was indicated also in Turkey (Demirtaş \& Ersözlü, 2010). The research findings indicate some cross-cultural differences in teachers' work satisfaction and job attractiveness.

Chinese teachers are dissatisfied with the material working conditions, opportunities for advanced studies, and the leadership (Xiaofu \& Qiwen, 2007). Jordanian teachers are less satisfied with their working conditions, children's social behaviors, and parent participation (Abu Taleb, 2013).

The good relationships with the colleagues and the heads are important for the effective work performance, because the research findings indicate that Canadian teachers whose needs for autonomy, competence, and relatedness were satisfied appeared to be in better psychological health and performed better their tasks (Brien, Hass \& Savoie, 2012). Relationship in the workplace are important for various kinds of occupation, because they are a factor determining career interests, performance, motivation, job satisfaction, and health.

The good relationships with other people increase the social feeling of community. The bad relationships with other people are often accompanied by a feeling of inferiority (in the case of lack of one's power) or a feeling of superiority (in the case of a more powerful own position in the society, among the peers, etc.) (Adler, 1997b). The rangers - sportsmen should have the strongest feeling of community, because they were more attracted by the good relationships at the workplace. 


\section{Conclusions and Future Study}

The findings from this study could be used in career consultation, motivational trainings and team-building.

Future studies on the link between relationships in the workplace and occupational attractiveness could focus on bigger samples from more professional groups in order to be established the moderating effect of such factors as age, work experience, gender, size of social networks, organizational climate, etc.

\section{References}

Abu Taleb, T. (2013). Job satisfaction among Jordan's kindergarten teachers: Effects of workplace conditions and demographic characteristics. Early Childhood Education Journal, 41 (2), 143-152. DOI: 10.1007/ s10643-012-0526-9

Adler, A. (1997a). Nauka žit [The science of living]. Kiev: Port-Royal.

Adler, A. (1997b). Ponât prirodu čeloveka [Understanding human nature]. Sankt-Peterburg: Akademičeskij proekt.

Alpass, F., Long, N., Chamberlain, K., \& MacDonald, C. (1997). Job satisfaction differences between military and ex-military personnel: The role of demographic and organizational variables. Military Psychology, 9 (3), 227-249. http://dx.doi.org/10.1207/s15327876mp0903_4.

Berry, A. B. (2012). The relationship of perceived support to satisfaction and commitment for special education teachers in rural areas. Rural Special Education Quarterly, 31 (1), 3-14.

Brien, M., Hass, C., \& Savoie, A. (2012). Psychological health as a mediator between need satisfaction at work and teachers' self-perceptions of performance. Canadian Journal of Behavioural Science / Revue canadienne des sciences du comportement, 44 (4), 288-299.

Courtright, K. E., \& Mackey, D. A. (2004). Job desirability among criminal justice majors: exploring relationships between personal characteristics and occupational attractiveness. Journal of Criminal Justice Education, 15 (2), 311-326. DOI: 10.1080/10511250400086001

Demirtaş, Z., \& Ersözlü, A. (2010). Liselerde görev yapan öğretmenlerin iş doyumu düzeyleri [The levels of job satisfaction of teachers who work high school]. e-Journal of New World Sciences Academy, Education Sciences, 5 (1), 199-209, Article Number: 1 C0124.

Fields, M. W., \& Shallenberger, W. R. (1987). The influence of age and education on perceptions of occupational attractiveness. Journal of Occupational Psychology, 60 (4), 339-342. DOI: 10.1111/j.20448325.1987.tb00266.x.

Hayward, M. D. (1986). The influence of occupational characteristics on men's early retirement. Social Forces (University of North Carolina Press), 64 (4), 1032-1045. DOI: 10.2307/2578793.

Hickling, E. J., Noel, R. C., \& Yutzler, F. D. (1979). Attractiveness and occupational status. Journal of Psychology, 102 (1), 71-76. DOI: 10.1080/00223980.1979.9915096.

Ivanov, I. (1999). Metodiki za izsledvane na uchitelia [Methods for study of the teacher]. Shoumen, Retrieved in November 2012, from http://www.ivanpivanov.com/research/.

Larkin, J. E., Laport, K. A., \& Pines, H. A. (2007). Job choice and career relevance for today's college students. Journal of Employment Counseling, 44 (2), 86-94. DOI: 10.1002/j.2161-1920.2007.tb00027.x.

Moses, B. (2003). What next? The complete guide to taking control of your working life. New York: DK Publishing.

Samuel, Y., \& Yuchtman-Yaar, E. (1979). The status and situs dimensions as determinants of occupational attractiveness. Quality \& Quantity, 13 (6), 485-502. DOI: 10.1007/BF00223000.

Slavchov, B., \& Stoyanova, S. (2007). Assessment of career motivational type. In E. Avram (Ed.), Psihologie organizational - manageriala. Perspective aplicative [Organizational psychology and psychology of management. Applied perspective] (Chapter 16, pp. 282-314). Bucuresti. Editura Universitara. 
Troman, G. (2008). Primary teacher identity, commitment and career in performative school cultures. British Educational Research Journal, 34 (5), 619-633. DOI: 10.1080/01411920802223925.

Weiner, H. R. (1990). Group-level and individual-level mediators of the relationship between soldier satisfaction with social support and performance motivation. Military Psychology, 2 (1), 21-32. DOI: 10.1207/ s15327876mp0201_2

Xiaofu, P., \& Qiwen, Q. (2007). An analysis of the relation between secondary school organizational climate and teacher job satisfaction. Chinese Education and Society, 40 (5), 65-77.

Advised by Jüratè Armoniene, Vilnius University, Lithuania

Received: May 30, 2016

Accepted: June 20, 2016

Nikolay Ivantchev $\quad \mathrm{PhD}$, Professor, Department of Psychology, SWU "Neofit Rilski", Blagoevgrad, Bulgaria.

Stanislava Stoyanova $\quad \mathrm{PhD}$, Professor, South-West University "Neofit Rilski”, Blagoevgrad, Bulgaria.

E-mail: avka@abv.bg

Website: https://www.swu.bg/?lang=en 